UDC 629.3.014.7+629.3.022.4

L.M. Petrov, PhD, Assoc.Prof., T.N. Borisenko

Odessa State Agrarian University, 13 Panteleymonovska Str., Odessa, Ukraine, 65012; e-mail: borisenko.taras@gmail.com

\title{
IMPROVEMENT OF THE COMBUSTION PROCESS OF DIESEL ENGINE FUEL
}

Л.М. Петров, Т.М. Борисенко. Удосконалення процесу згоряння палива дизельного двигуна. Для вирішення проблеми перетворення енергії палива у дизельному двигуні з метою підвищення його ККД необхідно створити додаткові умови для турбулізації робочої суміші. Запропоновано в робочий процес двигуна впровадити з певною частотою надлишки повітря, які створюють додаткові очаги згоряння палива й тим самим більш динамічне перетворення енергії палива в динамічний процес руху поршня. Для реалізації запропонованої технології використовували дизельні двигуни та мікрохвильові перепади тиску в зоні робочого процесу, яку створено поршнем та камерою згоряння. Вирішення проблеми повноцінного згоряння палива та підвищення ККД дизельного двигуна відбувалося шляхом створення в поршні отворів з перепускними клапанами. Вперше запропоновано технологію та конструкцію поршня з технологічною порожниною, який відрізняється від попередніх конструкцій наявністю пнемо- та вібропресингу повітря в об’ємі камери згоряння, що дозволяє значно підвищити ККД двигуна. Основні результати проведеної роботи були запатентовані під назвою патенту «Спосіб пневмопресингу робочої суміші дизельного двигуна».

Ключові слова: поршень, циліндр, камера згоряння, колінчастий вал, технологічна порожнина

L.M. Petrov, T.N. Borisenko. Improvement of the combustion process of diesel engine fuel. To solve the problem of converting fuel energy in the diesel engine in order to increase its efficiency, it is necessary to create additional conditions for the turbulence of the working mixture. It is proposed to introduce with a certain frequency of surplus air in the work process of the engine, which create additional sources of combustion of fuel and thereby more dynamic transformation of fuel energy into the dynamic process of motion of the piston. In order to realize the proposed technology, diesel engines and microwave differential pressures were used in the working process zone created by the piston and combustion chamber. Solving the problem of fuel combustion and increasing the efficiency of a diesel engine was carried out by creating the holes with relief valves in the piston. The technology and design of a piston with a technological cavity, which differs from previous designs with the presence of pneumatic and air vibropressing in the volume of the combustion chamber, is proposed for the first time, which allows to significantly increase the engine efficiency. The main results of the work were patented under the name of the patent "The method of pneumatic pressuring of the working mixture of a diesel engine".

Keywords: piston, cylinder, combustion chamber, crankshaft, technological cavity

Introduction. Transformation of fuel energy heated by compressed air into the mechanical work of the engine is carried out as follows. Internal combustion engines (ICEs) have a combustion chamber with a typical design, which is formed by the bottom of the piston and the head of the cylinder with an integral volume. In the cylinder there is an accelerating process of combustion of a fuel-air mixture throughout the volume of the combustion chamber. Increasing the power of engines with such a combustion chamber is possible only through the use of fuel with a high accent number.

Attempts to maximize the compression ratio of the fuel-air mixture, which determines the engine power, causes increased detonation processes, since the homogeneity and uniformity of the pressure distribution of gas combustion are disturbed. As a result, in the combustion chamber there is a very rapid movement of the mass of gas in the form of shock waves of compression and expansion.

The classic design of an ICE combustion chamber is formed by the piston head and cylinder head. It has an integral volume, in which the accelerating process of combustion of a fuel-air mixture over the entire volume of the combustion chamber [1] occurs.

World practice shows that in order to improve diesel engines, special attention should be paid to their basic output. The analysis of these indicators indicates that the maximum allowable compression ratio of the fuel-air mixture depends not only on the anti-knocking properties of the fuel, but also on the configuration of the combustion chamber.

In [2], it is shown how it is possible to convert the energy of fuel heated by compressed air into the mechanical work of the engine. In such an engine, the ring walls of the combustion chamber contain a cold and hot side. A large number of dilutions are made in the wall. 
A large number of dilutions are made in the wall. These openings allow the air to penetrate from the cold side of the wall to the hot side. Such a technological method is provided by combustion and dilution of a mixture of fuel and air.

In [3] the internal combustion engine with the following design is presented. It consists of, at least, one cylinder with a piston located therein, which is kinematically connected to the crankshaft.

The cylinder contains a head with inlet and outlet valves installed in it. At the bottom of the piston is a combustion chamber, made in the form of a recess from the body of rotation, whose axis coincides with the axis of the cylinder or is located near it

The vortexes of charge in the form of endings with tangential channels are located around the combustion chamber on the bottom of the piston and adjoin to the recess on the cylinder head at the position of the piston at the upper dead point (UDP).

The valves are located on the grooves in the cylinder head, the depth of which corresponds to the depth of the recess of the cylinder head and the height of the end faces at the bottom of the piston.

The ignition source - the nozzle - is installed in the drain of the cylinder head, with the combustion chamber and the end faces on the bottom of the piston made of cast iron or steel with low thermal conductivity and inserted or fixed to the bottom of the piston made of aluminum alloy.

In the engine, described in [4], the combustion chamber is formed by an external plane surface of the piston bottom and a deepening of the head in the form of segments. Segments of spherical surfaces have centers that are located on the extension of the axis of the valves.

In the electrodes area of the spark plugs there is an additional segment of the spherical surface. With such constructive performance, the working process of the piston engine of internal combustion is determined by the shape of its combustion chamber

The purpose of this work is to increase the efficiency of the diesel engine.

Materials and methods. Between the cylinder-piston group and the working body (combustible mixture) there are three forms of interaction:

- mechanical, which is carried out by moving the surface of the working body by a cylinderpiston group;

- heat, which is carried out through the surface of the working body in the presence of a temperature difference between it and the cylinder-piston group;

- mass exchange, which occurs as a result of joining or removing from the working body of elements of mass through the outer surface of the engine (muffler).

The process of connecting the mass of fuel to the working body consists of the stages of pushing out the spent working body and spent fuel, as well as the addition of new portions of fuel to the working mixture.

At the suction stage, the fuel mass element $d m$ falls to the volume of the working mixture. After that, the merging of two volumes and alignment of all the parameters of the working mixture elements that join it occurs.

Let the parameters of the working body to join the mass $d m$ were as follows: pressure $P$, specific volume $v$, temperature $T$, mass $m$ and specific internal energy $u$. After joining the mass, they changed to $d p, d v, d T, d m$ and $d u$. Then the volume occupied by the attached element in the volume of working mixture, we calculate according to the formula:

$$
d v=(v+d v) d m \approx d m .
$$

Work, which is spent on suction in the volume of the working mixture of the elementmass $d m$, will be determined by the formula:

$$
d L=(p+d p)(v+d v) d m \approx p v d m .
$$

Specific absorption work will be determined by the equation:

$$
d l=\frac{d L}{m}=\frac{p v d m}{m}=p v d c_{m},
$$

where $c_{m}$ - the relative magnitude of the mass of the attached element. 
The excess energy of an element of mass $d m$, which is attached to the working mixture, will be determined by the formula:

where $i$ - the enthalpy of an attached element;

$$
d U=\left(i_{n}-i_{0}\right) d m,
$$

$i_{0}$ - enthalpy of the working body.

When separating the mass $d m_{0}$ from the working body, the volume of the separated element will be determined by the formula:

$$
d V_{0}=(v+d v) d m_{0} \approx v d m_{0} .
$$

Exhaust of heated air from the body volume of the piston occurs due to the energy of air in the volume of the thermodynamic body - the piston. Therefore, the work of pushing $d L_{0}$ and negative work $d l_{0}$ will be calculated according to the formulas:

$$
\begin{aligned}
& d L_{0}=-p d V_{0}=-p v d m_{0}, \\
& d l_{0}=-\frac{p v d m_{0}}{m}=-p v d c,
\end{aligned}
$$

where $c$ - relative value of the separated mass of air.

The energy at the time of air separation, which began to flow into the engine cylinder from the entire mass, is superfluous. The energy that is present in the working space is zero, since the element of separated air has an enthalpy that is equal to the enthalpy of the elements of the working body - the piston.

When connecting and separating the masses of the air there is a mechanical and thermal interaction between the air and the piston cavities. In this case, the work on the mechanical interaction of the working mixture and structural elements that limit the working cavity, is determined by the formula

$$
d l=p v d c_{n}-p v d c_{0}=p v d c,
$$

where $d c=d c_{n}-d c_{0}=\frac{d m_{n}-d m_{0}}{m}=\frac{d m}{m}$.

The energy of the thermal interaction of the mass transfer between the working mixture and the constant detachable air mass $\mathrm{dm}$ is calculated as follows:

$$
d q_{n}=\left(i_{n}-i_{0}\right) d c_{n} .
$$

Equation of energy balance for unit of mass of air in the presence of heat transfer in the working cavity will have the form:

$$
d U=d q+\left(i_{n}-i_{0}\right) d c_{n}+d l+p v d c_{n}-p v d c_{0} .
$$

The internal energy of the whole air-changing weight, which has fallen into the engine cylinder, is determined by the formula

$$
U=u m \text {, }
$$

and the growth of this energy will be determined by the formula

$$
d U=m d u \cdot u d m \text {. }
$$

The change in the mass of air that enters the engine cylinder is determined by the formula

Then formula (1) takes the form

$$
d m=d m_{n}-d m_{0} .
$$

$$
d U=d Q+d L+i_{n} d m_{n}+i_{0} d m_{0} .
$$

We divide both parts of the equation into an infinitesimal amount of time and obtain the equation:

$$
\frac{d U}{d \tau}=\frac{d Q}{d \tau}+\frac{d L}{d \tau}+i_{n} \frac{d m_{n}}{d \tau}+i_{0} \frac{d m_{0}}{d \tau},
$$

where $d Q / d \tau$ - the flow of heat through the entire surface of the air, which is limited by a cylinder, a piston and a head of the combustion chamber;

$d L / d \tau$ - power supplied by the environment (elements of the engine) to the air that has fallen into the engine cylinder;

$d m_{n} / d \tau$ and $d m_{0} / d \tau$ - mass flow into the cavity of the piston of air particles, which, respectively, are joined and disconnected from its volume; 
$\tau$ - the infinitely small amount of time for which the particles (air) of the air are joined to (from) the total air volume.

The working processes in engines occur with a period corresponding to the time of one revolution of the crankshaft. Therefore, the analysis of engine working processes (with a modernized piston) is more convenient to carry out, depending on the angle of rotation $\varphi$ of the crankshaft, the value of which can be expressed by the equation:

$$
d \varphi=\omega d \tau,
$$

where $\omega$ - кутова частота обертання колінчастого валу.

When replacing in the equation of the variable $\tau$ on $\varphi$ we obtain the "equation of the energy processes of a diesel engine", whose piston is made with the technological cavity:

$$
d U=\left(\frac{1}{\omega}\right)\left[\frac{\omega d Q}{d \varphi}+\frac{\omega d L}{d \varphi}+i_{n} m_{n}+i_{0} m_{0}\right] d \varphi .
$$

The constituents of the equation (3) are depicted on the graphs. In fig. 1 space acquires the value of the heat flow for one spin of the crankshaft of the engine, in Fig. 2 - the value of the density of work per revolution of the crankshaft of the engine.

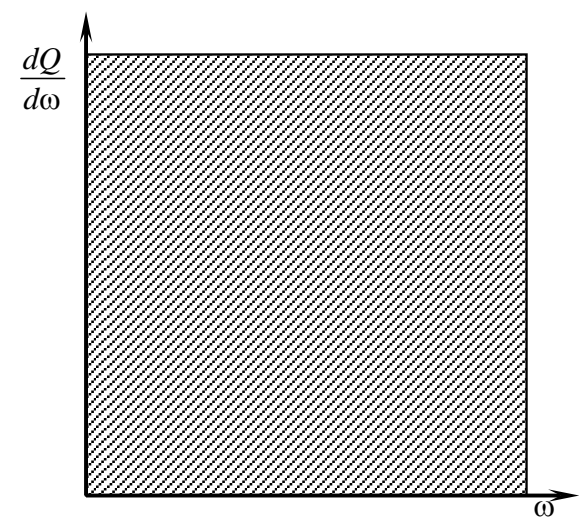

Fig. 1. Dependence of the density of the heat flow from the angular velocity of the crankshaft engine

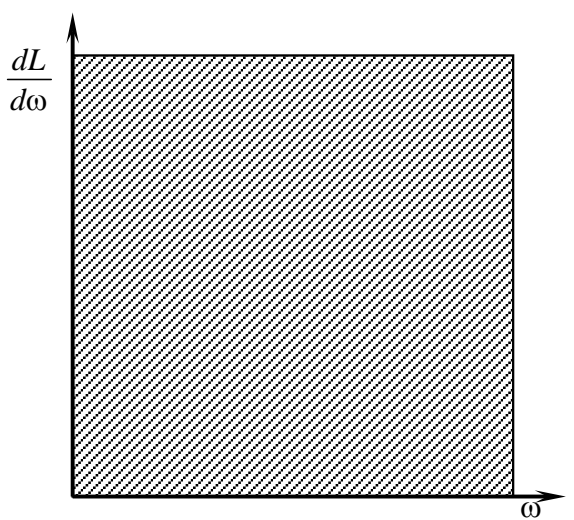

Fig. 2. The dependence of the density of work on the angular velocity of the crankshaft engine

Results. When overlaying the area, which is shown in Fig. 2, on the area on Fig. 1 we obtain the conditions for optimal operation of the cylinder-piston group of the engine in which the piston is made with the technological cavity (Fig. 3).

The first two components of the equation (3) $\frac{\omega d Q}{d \varphi}-$ and $\frac{\omega d L}{d \varphi}$, are responsible for improving the technology of converting fuel energy into the engine workflow. We propose such an estimation using the coefficient of improvement of the cylinder-piston group design $\left(k_{P B}\right)$ :

$$
k_{P B}=\frac{d L}{d Q} \text {. }
$$

From the above, we can draw the following conclusions.

We review of existing technologies of transformation of heat of combustion of fuel into the engine operation is carried out.

The constructive-technological scheme of conversion of fuel energy into the operation of a diesel engine has been

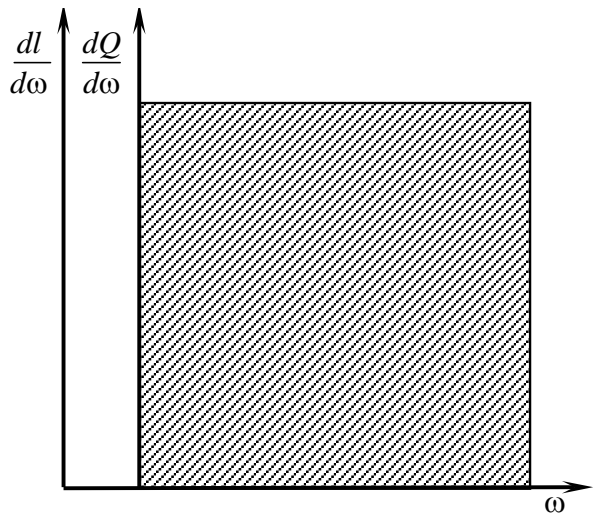

Fig. 3. Optimal operation mode of a cylinder-piston engine group with a technological piston cavity 
developed. An additional source of energy in the proposed scheme arises from the accumulation of energy in the technological cavity of the modernized piston.

A mathematical model of cylinder-piston group with a modernized piston has been developed.

The optimal mode of operation of the engine is substantiated, in which the work of the cylinderpiston group is completely spent on the implementation of heat in the working process of the engine.

On the basis of the presented material a patent was issued for the technological direction "The method of pneumatic pressuring of the working mixture of a diesel engine” [5].

\section{Література}

1. Пат. 104093 Україна, Камера згорання двигуна внутрішнього згорання / Маленко О.Ф.; патентовласник Маленко О. Ф. - № а201212549; заявл. 05.11.2012; опубл. 25.12.2013, Бюл № 24.

2. Пат. 2413134 Российская Федерация, Усовершенствование характеристик камеры сгорания посредством многократного перфорирования ее стенок / Бернье Д., Кампьен Жан-Мишель, Тушо С.; патентовласник СНЕКМА. - заявл. 17.10.2006; опубл. 27.02.2011, Бюл № 6.

3. Пат. 2411374 Российская Федерация, Двигатель внутреннего сгорания (ДВС) / Ахметов Э.Б.; патентовласник Ахметов Э.Б. - заявл. 01.06.2009; опубл. 10.02.2011, Бюл № 4.

4. Пат. №2405949 Российская Федерация. Дизельный двигатель внутреннего сгорания с камерами сгорания для высоких давлений воспламенения / Меллер Х., Ваккер М., Шпаниол П.; патентовласник МАН НУТЦФАРЦОЙГЕ АКЦИЕНГЕЗЕЛЛЬШАФТ. - заявЛ. 10.10.2006; опубл. 10.12.2010, Бюл № 34.

5. Пат. на корисну модель 109754 Україна, Спосіб «пневмо-пресингу» робочої суміші дизельного двигуна / Петров Л.М., Борисенко Т.М., Лисий О.В.; патентовласник Петров Л.М., Борисенко Т.М., Лисий О.В. - № u201600967 заявл. 08.02.2016, опубл. 12.09.2016, Бюл.№ 17

\section{References}

1. Malenko, O. F. (2013) Kamera zhorannya dvyhuna vnutrishn'oho z'horannya [Combustion chamber of internal combustion engine]. Ukraine Patent: UA 104093.

2. Bern'ye, D., Kamp'yen, Zhan-Mishel', \& Tusho, S. (2011) Usovershenstvovanye kharakterystyk kamery s.horanyya posredstvom mnohokratnoho perforyrovanyya ee stenok [Improvement of the characteristics of the combustion chamber by means of multi perforating its walls]. Russia Patent: 2413134.

3. Akhmetov, E.B. (2011) Dvyhatel' vnutrenneho s'horanyya (DVS) [Internal combustion engine (ICE)]. Russian Patent: 2411374.

4. Meller, K., Vakker, M., \& Shpaniol, P. (2010) Dyzel'nyy dvyhatel' vnutrenneho s.horanyya s kameramy $s$ horanyya dlya vysokykh davlenyy vosplamenenyya [Internal combustion diesel engine with combustion chambers for high ignition pressures]. Russia Patent:№2405949.

5. Petrov, L.M., Borisenko, T.M., \& Lisiy, O.V. (2016) Sposib "pnevmo-presynhu" robochoyi sumishi dyzel'noho dvyhuna [A method of pneumatic pressuring of a diesel engine working mixture]. Ukraine Patent: UA №109754. 